\title{
A synthesis of dominant ecological processes in intensive shrimp ponds and adjacent coastal environments in NE Australia
}

\author{
M.A. Burford $\dagger^{*}$, S.D. Costanzo ${ }^{\S}$, W.C. Dennison ${ }^{\S}$, C.J. Jackson†, A.B. Jones ${ }^{\S}$, \\ A.D. McKinnon ${ }^{\ddagger}$, N.P Preston $\dagger$, L.A. Trott ${ }^{\ddagger}$ \\ †CSIRO Marine Research, PO Box 120, Cleveland, Qld 4163, Australia \\ ${ }^{\S}$ Department of Botany, The University of Queensland, St Lucia, Qld 4072, Australia \\ ${ }^{\ddagger}$ Australian Institute of Marine Science, PMB No. 3, Townsville Qld 4810, Australia
}
Keywords: aquaculture, impacts, sustainability, bioindicators, nutrients, ecosystem processes
*Corresponding author. Centre for Riverine Landscapes, Griffith University, Nathan, Queensland 4111, Australia, Tel.: +61 738756723

E-mail address: m.burford@griffith.edu.au 


\begin{abstract}
One of the key environmental concerns about shrimp farming is the discharge of waters with high levels of nutrients and suspended solids into adjacent waterways. In this paper we synthesize the results of our multidisciplinary research linking ecological processes in intensive shrimp ponds with their downstream impacts in tidal, mangrove-lined creeks. The incorporation of process measurements and bioindicators, in addition to water quality measurements, improved our understanding of the effect of shrimp farm discharges on the ecological health of the receiving water bodies. Changes in water quality parameters were an oversimplification of the ecological effects of water discharges, and use of key measures including primary production rates, phytoplankton responses to nutrients, community shifts in zooplankton and $\delta^{15} \mathrm{~N}$ ratios in marine plants have the potential to provide more integrated and robust measures. Ultimately, reduction in nutrient discharges is most likely to ensure the future sustainability of the industry.
\end{abstract}

\title{
Introduction
}

Sustained global demand for shrimp, which cannot be met by fisheries alone, continues to provide a strong economic incentive for intensive shrimp farming. However, the adverse environmental impacts resulting from the uncontrolled expansion of shrimp farming in many coastal regions in the tropics and sub-tropics have prompted widespread criticism (Naylor, Goldburg, Mooney, Beveridge, Clay, Folke et al.,1998) and global efforts to develop more sustainable farming techniques (Preston, Rothlisberg, Burford \& Jackson, 2001).

One of the key concerns is the effect of the periodic discharge of shrimp pond water that contains high concentrations of suspended solids and nutrients, particularly nitrogen $(\mathrm{N})$, relative to intake levels (Jackson, Preston, Thompson \& Burford, 2003). Discharging water from ponds is a common management practice to ensure adequate water quality for shrimp growth. The discharge of high loads of nutrients and suspended solids has the potential to have adverse effects on the receiving waters, including stimulating algal blooms and creating anoxic conditions (Naylor et al., 1998; Smith, Tilman \& Nekola, 
1999). It has been calculated that a mangrove area of 2 to 22 ha is required for assimilation of wastes from each ha of shrimp ponds (Robertson \& Phillips, 1995).

The potential adverse effects of prawn farm discharges in coastal waters are widely referred to, but poorly documented in rigorous scientific studies. Concentrations of water quality parameters have shown short term increases in a creek receiving shrimp discharge waters, but there were no significant differences over background levels on an annual basis (Trott \& Alongi 1999, 2000). In part this is due to the high degree of natural variability in water quality parameters.

In Australia, the shrimp industry is relatively small (2,700 Mt p.a. production, 500 ha pond area) and highly regulated. Concerns about the potential adverse effects of shrimp farm discharges, together with a lack of effective environmental indicators and compliance measures, have been factors constraining sustainable development (Preston et al., 2001). This constraint provided the impetus for a multidisciplinary study to develop a quantitative understanding of the effects of high nutrient loads within ponds and in the ecosystems that receive pond discharges. This review synthesizes the research advances achieved using this multidisciplinary approach and their implications for improved regulation of shrimp farming within coastal environments.

\section{Study Area}

The two study areas in tropical north Queensland, Australia each had a shrimp farm on a tidally-dominated mangrove creek that received substantially lower freshwater input in the dry season (May to November) than in the monsoonal wet season (December to April) (Fig. 1).

The study area near Farm $1\left(16^{0} 29^{\prime}\right.$ S, $145^{\circ}$ 27’ E) was a large creek, Muddy Creek (6.9 km long, $3 \mathrm{~m}$ tidal range) that was surrounded by mangrove forests, salt marshes and intertidal saltpans and received discharge water from 13.5 ha. of ponds in Farm 1 (Table 1). The creek also periodically received rainfall runoff from sugar cane farms. The control creek was nearby Sandfly Creek which was sinuous, narrow (2-3 m wide) 
and approximately $4.4 \mathrm{~km}$ long. The mouth of the creek was partially occluded by a sand/mud bar at spring low tides. Both Muddy and Sandfly creeks were shallow, seldom deeper than 1 to $2 \mathrm{~m}$ in depth at low tide. The lower reaches of these creeks were flushed efficiently by tidal action, but significant water trapping occurred at times in the upper reaches (Wolanski, 1992). There were five sampling sites in Muddy Creek and four in Sandfly Creek.

The study site near Farm 2 (18 20 'S; $146^{\circ} 4^{\prime}$ E) was a mangrove-lined creek, Pig Creek (2.2 km long, $3.5 \mathrm{~m}$ tidal range) which received discharge water from 30 ha of ponds at Farm 2 (Fig. 1). The adjacent control creek, Morris Creek, was deeper (2-3m), wider (30 $-50 \mathrm{~m}$ ) and relatively straight for the first $1.5 \mathrm{~km}$ below the farm, then had a major creek tributary near the mouth (total length 2.2. km) (Table 1). There were four sampling sites in Pig Creek and five in Morris Creek.

Farm 1 was stocked with the black tiger shrimp, Penaeus monodon at a density of 25 to 35 animals $\mathrm{m}^{-2}$. Ponds were typically 1 ha in size with earthen floors. Commercial feed (30 - 42\% protein) was added to ponds throughout the period of this study with inputs increasing as shrimp grow. Feed tables, based on \% of shrimp body weight, and feed trays were used to determine feed input (Jory, Cabrera, Durwood, Dugger, Fegan, Lee et al., 2001). Feed is the main nitrogen input (90\%) to intensive shrimp ponds (Briggs \& Funge-Smith 1994; Jackson et al. 2003). Ponds were aerated and mixed with paddlewheels creating an inner zone of flocculated sludge containing waste products from feeding and other detritus, and an outer zone of sand and rubble swept clean by action of the paddlewheels. Water exchanges from ponds varied according to the stage of the growth cycle, ranging from $0 \%$ in the first month after stocking to up to $30 \%$ volume per week during the final growth stages and harvesting. Net nitrogen discharged was $1.18 \mathrm{~kg} \mathrm{ha}^{-1}$ pond area d ${ }^{-1}$ (Trott, McKinnon, Alongi, Davidson \& Burford, in press). Ponds were harvested after 4 to 5 mo.

Farm 2 was stocked with the banana shrimp, Penaeus merguiensis at a density of 25 to 35 animals $\mathrm{m}^{-2}$. The ponds were managed using similar principles to Farm 1. As with Farm 
1, water exchanges increased with the stage of the cropping cycle. The main daily pond exchange rate over the growth season was 3.9\%, and net nitrogen discharged was $0.99 \mathrm{~kg} \mathrm{ha}^{-1}$ pond area $\mathrm{d}^{-1}$ (Jackson et al., 2003).

\section{Analyses and calculations}

In preparing this synthesis, we have drawn on published data relating to the ecological processes in the creeks at the two study sites and data on a range of shrimp ponds with similar management practices (Table 2). Water quality and flow, and rates of $\mathrm{N}$, carbon (C) and oxygen flux in the water column and sediment were determined for a number of sites and sampling occasions during both the discharge and non-discharge periods over a three year period (Tables 3, 4, 5, 6). Pelagic process measurements were conducted at high tide between 0700 and $0900 \mathrm{~h}$ to standardize daylight incubations of bottle experiments and to allow boat access to all sites on the same day (Trott \& Alongi, 2001). The water column was considered to be fully mixed during spring tides and most neap tides based on previous measurements of nutrients and suspended solids over $24 \mathrm{~h}$ periods (Wolanski, Spagnol, Thomas, Moore, Alongi, Trott \& Davidson, 2000; Trott, unpubl. data).

A range of bioindicators were also used near Farm 2: $\delta^{15} \mathrm{~N}$ stable isotope ratios in leaves

collected from mangroves growing on the banks of the creek, $\delta^{15} \mathrm{~N}$ stable isotope ratios in the red macroalgae, Catenella nipae which was incubated in the creeks for a few days, and phytoplankton bioassays. Phytoplankton bioassays involved determining the response of phytoplankton to nutrients by incubating water samples in bags for $7 \mathrm{~d}$ with and without nitrate, ammonium, phosphate and silicate addition, and measuring changes in fluorescence (Costanzo, 2001). The results were expressed as:

PRI (phytoplankton response index) $=\left(F_{N}-F_{C N}\right) / T_{N}$ Where $\mathrm{F}_{\mathrm{N}}=$ maximum fluorescence, $\mathrm{F}_{\mathrm{CN}}=$ fluorescence in control treatment and $\mathrm{T}_{\mathrm{N}}=$ time to reach maximum fluorescence.

For the bioindicator monitoring, there were three sampling periods in the creeks near Farm 2 at different stages of the shrimp grow-out phase; empty ponds, full production, 
and at harvest when ponds were being emptied. All sampling occurred near the top of the flood tide for bioindicator assays.

For the shrimp ponds, water quality measurements and rates of N, C and oxygen flux in the water column and sediment were determined at a number of farms along the east coast of Australia that had similar pond management practices, shrimp stocking densities $\left(25-35\right.$ animals $\left.\mathrm{m}^{-2}\right)$, food conversion ratios (FCR $\left.=1.8\right)$ and shrimp harvest tonnages $\left(5 \mathrm{tha}^{-1} \mathrm{crop}^{-1}\right.$ ) (Tables 3, 4). Feed was the main nutrient input ( $90 \%$ of $\mathrm{N}$ ) to these intensive shrimp ponds (Jackson et al., 2003), therefore waste loads discharged from farms were likely to be similar across farms and comparable with Farms 1 and 2.

Flux measurements have been converted from the original literature into standard units of mmol m $\mathrm{m}^{-2} \mathrm{~d}^{-1}$, assuming water depths of $1.5 \mathrm{~m}$ within the pond systems, $1 \mathrm{~m}$ creek depth near the shrimp farm discharge points, and 2.5m deep further downstream in the 0 to 2 $\mathrm{km}$ downstream of the farm.

Two zones were identified in the creeks based on the water quality data: the first $2 \mathrm{~km}$ downstream of the shrimp farms where concentrations of water quality parameters (principally total $\mathrm{N}$, total $\mathrm{P}$ and chlorophyll $a$ ) were higher than those in the control creeks; and $>2 \mathrm{~km}$ downstream of the shrimp ponds in the creeks receiving discharge where water quality parameters were equivalent to the control creeks. Therefore, data from the $>2 \mathrm{~km}$ downstream zones and control creeks for water quality parameters and ecological processes were combined.

Overall, concentrations of water quality parameters and ecological processes were similar in the two control creeks for most parameters and therefore the results were combined. The same was true for Muddy and Pig Creeks. The lack of differences between the creeks was due, in large part, to the high temporal variability in water quality parameters and the magnitude of ecological processes. 
In order to characterize the productivity of these environments, the definitions of Nixon (1995) for C input rates were used. Due to the high C inputs from both primary productivity and formulated feed inputs in intensively managed aquaculture ponds, it was necessary to add a new category to those of Nixon (1995). We have coined the term "ultratrophic", defined as waters with inputs of $>700 \mathrm{~g} \mathrm{C} \mathrm{m}^{-2} \mathrm{y}^{-1}$ with Nixon's (1995) term, "hypertrophic" being changed to $501-700 \mathrm{~g} \mathrm{C} \mathrm{m}^{-2} \mathrm{y}^{-1}$. In our system, the ponds themselves and the receiving waters 0 to $2 \mathrm{~km}$ downstream were ultratrophic, and those $>2 \mathrm{~km}$ downstream were eutrophic (301 - $500 \mathrm{~g} \mathrm{C} \mathrm{m}^{-2} \mathrm{y}^{-1}$, Nixon, 1995).

\section{Ecological Processes}

Early and late growth stage ponds

Our studies have shown that in the first 1 to 2 months in the growout season, $\mathrm{C}$ and $\mathrm{N}$ inputs to ponds were small, comprising the initial stocking with postlarval shrimp, and a low input of formulated feed and fertilizers. Nutrient and chlorophyll $a$ concentrations, and microbial abundance were relatively low compared to later in the growth season (Table 3). Mesozooplankton abundance was high for the first few weeks after shrimp are stocked (Preston, Coman \& Fry, in press; Coman, Connelly \& Preston, in press). There was no water exchange from the ponds.

Late in the growth season (4 to 5 months after stocking), feed inputs were an order of magnitude higher to satisfy the nutritional requirements of the increased biomass of shrimp. Much of this feed (70-80\%) was not assimilated by the shrimp but entered the pond system as both dissolved and particulate N and P (Table 3). Phytoplankton, as measured by chlorophyll $a$, were major contributors to the particulate $\mathrm{N}$ and $\mathrm{P}$ concentrations (Jackson et al., 2003). Dissolved organic N (DON) originating from the feed was not readily utilized by the microbial community and accumulated in the water column (Burford, 2000; Burford \& Williams, 2001). However, urea (a component of the DON pool) was rapidly cycled through the pond system (Burford \& Glibert, 1999).

The action of the aerators resulted in the accumulation of fine inorganic material, waste products from feeding and other detritus in the pond centre (Burford, Peterson, Baiano \& 
Preston, 1998; Peterson, 1999). The sludge mound was anoxic with high rates of carbon dioxide and ammonium release $\left(28 \mathrm{mmol} \mathrm{m}^{-2} \mathrm{~d}^{-1}\right)$ as the waste products from feeding were mineralized (Table 4) (Burford \& Longmore, 2001). To a lesser extent, ammonium was also generated from shrimp excretion $\left(11 \mathrm{mmol} \mathrm{m}^{-2} \mathrm{~d}^{-1}\right)$ and regeneration processes $\left(83 \mathrm{mmol} \mathrm{m}^{-2} \mathrm{~d}^{-1}\right)$ in the water column (Burford \& Glibert, 1999; Burford \& Williams, 2001).

The released ammonium was rapidly utilized, with $90 \%$ of the uptake by the $<10 \mu \mathrm{m}$ fraction of the phytoplankton and bacterial community, which were present in high numbers (chlorophyll $a$ concentrations, $60-150 \mu \mathrm{g} \mathrm{l}^{-1}$, bacterial numbers, $3 \times 10^{6} \mathrm{ml}^{-1}$ ). Primary production rates were also high (Burford, 1997) (Table 4). Microzooplankton were also present in high numbers, presumably feeding on the bacteria and detritus $\left(>10^{5}\right.$ $\mathrm{ml}^{-1}$, Burford, 2000). Mesozooplankton numbers were low $\left(<3\right.$ animals $\mathrm{L}^{-1}$, Preston et al., 2003). Much of the microbial community (autotrophs and heterotrophs) was ultimately sedimented, contributing to the sludge mound (Burford \& Longmore, 2001; Jackson et al., 2003).

The main $\mathrm{C}$ and $\mathrm{N}$ outputs from the ponds were via routine water discharges (Jackson et al., 2003). Most of the dissolved $\mathrm{N}$ was in the form of ammonium and DON (>90\%), and much of the particulate $\mathrm{N}$ was phytoplankton. Little of the $\mathrm{N}$ was lost via denitrification ( $<2 \%$ of $N$ input, Burford \& Longmore, 2001) and, based on studies in catfish and shrimp ponds, it is assumed that little (3.7\% of ammonium) was lost via ammonia volatilization (Gross, Boyd \& Wood, 1999; A. Gross, unpubl. data).

\section{0-2 km downstream from the farm}

Concentrations of water quality parameters were lower, but highly variable, in the water column in the first 0 to $2 \mathrm{~km}$ downstream of the farms during both discharge and nondischarge periods, however the differences with the farms were more marked during nondischarge periods (Table 5) (McKinnon, Trott, Alongi \& Davidson, 2002a). The most pronounced differences between the shrimp ponds and the downstream were 
chlorophyll $a$, ammonium and total $\mathrm{N}$ concentrations. Primary production rates were comparable with the shrimp ponds (Table 6) (McKinnon et al., 2002a). A substantial percentage of the $\mathrm{N}$ ( $25 \%$ ) discharged from the shrimp farm was transformed by the phytoplankton ( 15\%) and microbial community ( 10\%) in the ultratrophic zone of the creek. Phytoplankton assimilated ammonium at rates comparable with those in the shrimp ponds early in the growth season.

Microzooplankton were the most important grazers in the upper reaches of the creek during both discharge and non-discharge periods. Despite the high grazing pressure, both phytoplankton and bacteria production greatly exceeded grazing, i.e. grazing was saturated, during discharge periods (McKinnon, Trott, Cappo, Miller, Speare \& Davidson, 2002b). In addition, juvenile fish were detected in large numbers near the shrimp farm discharge point, and appeared to be feeding indiscriminately (McKinnon et al., 2002b). The dominant groups of fish occurring at these locations, clupeins and engraulins, can filter-feed (Milton, Blaber \& Rawlinson, 1990, 1994), and it is likely that particulate matter originating from the shrimp farm was directly assimilated by these species.

Sedimentation rates of both $\mathrm{C}, \mathrm{N}$ and $\mathrm{P}$ in the 0 to $2 \mathrm{~km}$ downstream of the farm were higher than further downstream, but the proportion of water column nutrients that sedimented was lower, with the exception of C (Table 6) (Trott \& Alongi, 2001). Despite high sedimentation and burial rates, there were relatively low rates of benthic respiration compared with the shrimp ponds, with no indication of anoxic sediments (Table 6). Benthic ammonium fluxes were also low. Denitrification rates were similar to shrimp ponds and were estimated to remove only $6 \%$ of $\mathrm{N}$ discharged from the farm.

$\delta^{15} \mathrm{~N}$ stable isotope ratios were higher in both mangrove leaves and macroalgae in the first 1 to $2 \mathrm{~km}$ downstream of the discharge point from Farm 2 than in the control creek (Table 7) (Costanzo, 2001). The effect of nutrient additions on stimulating phytoplankton growth, as measured by phytoplankton bioassays, was greater in the control creek than the 0-2 km zone (Table 7). Phytoplankton responses to nutrients were 
also higher during non-discharge periods in the 0-2 km zone than when water was being discharged. During this time, nutrient concentrations in the water column were lower. Therefore, the results suggest that at these concentrations, nutrients are limiting phytoplankton growth.

\section{$>2 \mathrm{~km}$ downstream from the shrimp farms}

Nutrient and chlorophyll $a$ concentrations in the lower reaches of the creeks were generally lower than in the 0 to $2 \mathrm{~km}$ zone near Farms 1 and 2 irrespective of whether the farms were discharging or not (Table 5) (Trott \& Alongi, 2001). However, the most pronounced changes were in bacterial and primary productivity, and grazing. The primary productivity was three to four fold lower $>2 \mathrm{~km}$ downstream while the bacterial production was half (Table 6, McKinnon et al., 2002b). Bacterivory by zooplankton was lower than in the 0 to $2 \mathrm{~km}$ zone. Grazing of both phytoplankton and bacteria greatly exceeded production. In addition, the contribution of the mesozooplankton to total grazing pressure increased compared with the 0-2 km zone (McKinnon et al., 2002b). The mesozooplankton community was composed almost exclusively of small copepods that primarily feed on protists. It is likely therefore, that material initially grazed by protist grazers in the upper reaches of the creek was further transformed by trophic processes in the lower reaches of the creek.

Fish species that occurred in both zones appeared to differ in their mode of feeding (McKinnon et al., 2002b). Whereas filter feeding was a common feeding strategy upstream, in the lower reaches it appeared to be replaced by more selective predation on benthic epifauna and zooplankton.

Sedimentation rates and rates of oxygen consumption, denitrification and ammonium fluxes from the sediment were similar in the lower creek to the upper creek (Table 6) (Trott \& Alongi, 2001).

$\delta^{15} \mathrm{~N}$ values in the mangrove leaves and macroalgae in the lower reaches of the creek were lower than further upstream, but not as low as in the control creek (Table 7) 
(Costanzo, 2001). The phytoplankton response to nutrients was higher downstream during discharge periods than non-discharge periods (Table 7).

\section{Summary of trends}

The ultratrophic (>700 g C m $\mathrm{m}^{-2}$ ) shrimp ponds had the highest chlorophyll $a$, total $\mathrm{N}$ and P concentrations of $167.7 \mu \mathrm{g} \mathrm{L}^{-1}, 231.0 \mu \mathrm{M} \mathrm{N}$ and $11.7 \mu \mathrm{M}$ P respectively). In the ultratrophic zone 0 to $2 \mathrm{~km}$ downstream, concentrations of chlorophyll $a$, total $\mathrm{N}$ and $\mathrm{P}$ were lower (43.4 $\mu \mathrm{g} \mathrm{L}^{-1}, 65.5 \mu \mathrm{M} \mathrm{N}$ and $4.1 \mu \mathrm{M}$ P respectively during discharge, and $2.3 \mu \mathrm{L} \mathrm{L}^{-1}, 44.5 \mu \mathrm{M} \mathrm{N}$ and $2.6 \mu \mathrm{M}$ P respectively during non-discharge); they decreased further in the eutrophic downstream environment $\left(2.2 \mu \mathrm{g} \mathrm{L}^{-1}, 19.1 \mu \mathrm{M} \mathrm{N}\right.$ and $1.1 \mu \mathrm{M} \mathrm{P}$ respectively). Concentrations of water quality parameters in all zones were highly variable, often varying by an order of magnitude.

The data on mean nitrogen and phosphorus pools and fluxes (Tables 3,4,5,6) were combined into conceptual models for comparison of late season shrimp ponds, 0-2 km downstream (during shrimp farm discharge periods) and $>2 \mathrm{~km}$ downstream zones (Figs. 2,3). Most parameters decreased in magnitude through the three zones with the exception of denitrification rates and phosphate concentrations, both of which were low in comparison with other pools and fluxes. Additionally net fluxes of phosphate from the sediment changed from positive in the shrimp ponds to negative downstream. The low phosphate:dissolved nitrogen ratio in the water column suggests that phosphate, rather than nitrogen, was likely to be a limiting nutrient to phytoplankton growth, particularly downstream from the farm where the net flux of phosphate was into the sediment.

In contrast to the decrease in nutrient concentrations in a gradient away from the shrimp farm, primary productivity was comparable $\left(>700 \mathrm{~g} \mathrm{C} \mathrm{m}^{-2} \mathrm{y}^{-1}\right)$ in the 0 to $2 \mathrm{~km}$ downstream zone and the shrimp ponds. Despite the decrease in soluble nutrients, the high primary productivity suggests that sufficient nutrients remain available to promote phytoplankton growth. Further downstream, decreased nutrient concentrations combined with increased grazing pressure resulted in a eutrophic zone with considerably lower 
primary productivity (301-500 $\mathrm{g} \mathrm{C} \mathrm{m}^{-2} \mathrm{y}^{-1}$ ). Tidal exchange and dilution are also likely to have contributed to this reduction (Trott \& Alongi, 2000; McKinnon et al., 2002a).

Changes in zooplankton grazing patterns across the trophic zones also gave insights into the effect of shrimp farm discharges. The microzooplankton inoculum from the ponds is likely to have contributed to the high microzooplankton grazing rates in the ultratrophic zone downstream from the farm. In contrast, mesozooplankton grazing was low in this zone, consistent with low numbers of mesozooplankton in the shrimp ponds (Preston et al., in press). Further downstream the zooplankton community was more typical of coastal waters with a higher mesozooplankton: microzooplankton ratio (McKinnon \& Klumpp 1998; McKinnon et al., 2002b).

Despite the effect of shrimp farm discharges on water quality and water column processes in the receiving waters, there was no obvious effect on sediment processes. This is surprising in light of the high sedimentation rates that might be expected to produce anoxic conditions, and hence increase ammonium and phosphate release rates. One possible explanation is that sediments were regularly resuspended and moved downstream by the scouring action of strong spring tide currents, as well as the episodic rainfall events that occur in this area. The site of deposition of sediments in the longer term is unknown.

The phytoplankton response in the bioassays suggest a 'trade-off' between the initial standing stock of phytoplankton and the ability to respond to nutrients (Costanzo, 2001). This was particularly apparent in the 0 to $2 \mathrm{~km}$ zone where there was no response to nutrients despite an increased phytoplankton biomass and productivity. The lack of response was probably because there were already sufficient nutrients for optimal growth in this zone. However, in the eutrophic zone, the phytoplankton were likely to be nutrient limited due to the lower nutrient concentrations, resulting in a much greater response to nutrient addition. 
Marine macrophytes were also used as bio-indicators due to their ability to assimilate processed N such as that from shrimp ponds (Costanzo, O’Donohue, Dennison, Loneragan \& Thomas, 2001; Jones, O’Donohue, Udy \& Dennison, 2001a). N from shrimp ponds has a higher $\delta^{15} \mathrm{~N}$ ratio than marine or terrestrial sources of $\mathrm{N}$ (Preston. Unpub. data). Both mangrove leaves and macroalgae in our study had elevated tissue $\delta^{15} \mathrm{~N}$ signatures in the ultratrophic zone and beyond to the mouth of the creek. This indicates that the plants in this zone were assimilating nutrients discharged from the farms. This contrasts with the water quality parameters which reach ambient concentrations within the 0 to $2 \mathrm{~km}$ zone.

\section{Implications of the study}

Characterizing ultratrophic ecosystems

Coastal and estuarine waters receive nutrient imports from a variety of anthropogenic and natural sources. The characteristics of shrimp farm discharges are qualitatively different from other major sources of nutrients. Nutrients in shrimp ponds are derived from fishmeal-based feeds while pond erosion causes inorganic particles to be suspended in the water column. The resulting discharge water has high concentrations of inorganic particles, phytoplankton, particulate and dissolved organic compounds, and ammonium derived from these feeds (Ziemann, Walsh, Saphore \& Fulton-Bennett, 1992; Jackson et al., 2003). In contrast, human sewage is derived principally from terrestrial-based food, and treated sewage effluent has a high proportion of ammonium and nitrate, but low concentrations of phytoplankton, particulate nutrients and inorganic particles (Jones et al., 2001a). Agricultural runoff is derived from fertilizers and soil, and has high concentrations of particulate nutrients, nitrate and suspended inorganic particles (Eyre, 1993).

The unique characteristics of shrimp aquaculture discharges means that impact assessment techniques have to be different to those for sewage or agriculture. Our study has shown that the predominant effects of shrimp aquaculture discharge were in the water column processes, rather than sediment processes. This is likely to be a reflection of the magnitude of the discharge loads from the shrimp farms (16 to $30 \mathrm{~kg} \mathrm{~N} \mathrm{~d}^{-1}$ ), and the 
hydrodyamics of the receiving waters. The lack of detectable impacts on sediment processes was due, in part, to the tidal dynamics and major pulsed rainfall events transporting sediments down the creeks. Tidal energy and residence times are attributes of the waterbody that strongly shape the expression of eutrophication (Cloern, 2001). In the case of Muddy Creek, the residence time was between 4 and $15 \mathrm{~d}$ (Wolanski, et al., 2000). The high rates of phytoplankton and bacterial production suggest that the activity of these organisms was an important control of dissolved nutrient concentrations in these creeks. Grazing within the water column, principally by the microzooplankton, was the biological process most responsible for the observed decreases in standing stocks of bacteria, phytoplankton and micro-particulate materials.

The concentrations of water quality parameters measured in shrimp ponds in this study were comparable with those in intensive shrimp ponds in other areas of the world (Briggs \& Funge-Smith, 1994; Páez-Osuna, 2001; Alonso-Rodríguez \& Páez-Osuna, 2003). There are few other studies of $\mathrm{N}, \mathrm{C}$ and $\mathrm{P}$ cycling in intensive shrimp ponds with which to compare this study, but the literature on fish ponds is more extensive. As was the case in this study, denitrification rates in fish ponds were generally low relative to $\mathrm{N}$ inputs (Hargreaves, 1998). In contrast, fluxes of ammonium from the sediment were found to be a significant source of ammonium to the water column in both this study and studies of fish ponds (Burford \& Longmore, 2001). Primary productivity (200 mmol C m $\mathrm{m}^{-2}$ ) and ammonium uptake (100 $\left.\mathrm{mmol} \mathrm{N} \mathrm{m}^{-2} \mathrm{~d}^{-1}\right)$ by phytoplankton in this study were comparable with other studies in fish ponds (80-800 $\mathrm{mmol} \mathrm{C} \mathrm{m}^{-2} \mathrm{~d}^{-1}$ and $10-110 \mathrm{mmol} \mathrm{N}$ $\mathrm{m}^{-2} \mathrm{~d}^{-1}$ ) (Hargreaves, 1998).

There have been few studies of the effect of shrimp farm discharges on water quality and ecological processes in tidal creeks. However, ecological processes have been measured in other creeks not receiving significant anthropogenic inputs. Alongi, Ayukai, Brunskill, Clough \& Wolanski (1998) found lower benthic and pelagic respiration rates $\left(1.65 \times 10^{7} \mathrm{M} \mathrm{C}_{\text {org }} \mathrm{y}^{-1} \mathrm{~km}^{-2}\right)$ than those in the $0-2 \mathrm{~km}$ zone of the impacted creek in our study (2.1 $\mathrm{M} \mathrm{C}_{\text {org }} \mathrm{y}^{-1} \mathrm{~km}^{-2}$ ). Particulate organic $\mathrm{C}$ exports from similar mangrove creeks in the region of this study were 3,322 $\mathrm{kg} \mathrm{C} \mathrm{ha}^{-1} \mathrm{y}^{-1}$ (Robertson \& Blaber, 1992) compared 
with 4,680 kg C ha- ${ }^{-1}{ }^{-1}$ from the $0-2 \mathrm{~km}$ zone of Muddy Creek. Primary productivity in the $0-2 \mathrm{~km}$ zone of Muddy Creek was higher $\left(1200 \mathrm{~g} \mathrm{C} \mathrm{m}^{-2} \mathrm{y}^{-1}\right)$ than that measured in other coastal water bodies $\left(74-470 \mathrm{~g} \mathrm{C} \mathrm{m}^{-2} \mathrm{y}^{-1}\right.$ ) (Alonso-Rodríguez \& Páez-Osuna, 2003).

Fluxes of $\mathrm{N}$ were higher in Muddy Creek than that measured in other mangrove creek systems: an net annual flux of 10,234 $\mathrm{kg} \mathrm{N} \mathrm{y}^{-1}$ has been estimated from an extensive mangrove system $\left(42.5 \mathrm{~km}^{2}\right)$ at Missionary Bay, northern Australia (Alongi, Boto \& Robertson, 1992) compared with 6,412 $\mathrm{kg} \mathrm{N} \mathrm{y}^{-1}$ from Muddy Creek with an area of only $0.01 \mathrm{~km}^{2}$. Denitrification rates in Muddy Creek $\left(1.37-1.61 \mathrm{mmol} \mathrm{N} \mathrm{m}^{-2} \mathrm{~d}^{-1}\right)$ were comparable with the range of values in other coastal marine systems $(0.024-4.8 \mathrm{mmol} \mathrm{N}$ $\mathrm{m}^{-2} \mathrm{~d}^{-1}$ ) (Seitzinger, 1988; Rivera-Monroy \& Twilley, 1996). In contrast, ammonium fluxes from the sediment were low compared with other studies in estuarine and marine systems (Hargreaves, 1998).

\section{Monitoring impacts of aquaculture}

In many countries, including Australia, government agencies have set discharge limits from aquaculture facilities that are generally based on loads or concentrations of N, P and other water quality parameters. These parameters have been shown to fluctuate significantly over short periods of time (Wolanski et al., 2000) and it is therefore difficult to develop water quality sampling strategies that accurately reflect temporal and spatial trends.

An alternative approach to assessing the effects of aquaculture discharges is the measurement of the key ecological processes and indicators. Concentrations of water quality parameters are only proxies for ecological processes and, as our results have shown, can be highly variable. Our study has identified some key processes and indicators which both integrated changes in water quality and revealed greater impacts than that shown by water quality parameters. These are: primary production rates; phytoplankton responses to nutrients; community shifts in zooplankton and fish grazing patterns; and elevated $\delta^{15} \mathrm{~N}$ ratios in marine plants. Whilst the measurement of these 
parameters is more labour intensive than water quality measurements, they provide more meaningful information about ecological impacts. The challenge is, therefore, to develop practical, cost-effective monitoring techniques that reflect these processes.

A more significant challenge is to develop new indicators that can differentiate shrimp farm discharges from other loads, and to identify ecosystem attributes that relate to the community-derived environmental values. The use of $\delta^{15} \mathrm{~N}$ ratios in marine plants, for example, is only useful in waterways where sewage discharges do not confound the interpretation. Human sewage also has an elevated $\delta^{15} \mathrm{~N}$ ratio (Heaton, 1986), making it difficult to differentiate between sewage and shrimp farm discharge (Jones et al., 2001a).

\section{Mitigation}

The most effective way of reducing the impacts of aquaculture in aquatic waterways is by minimizing discharges. Since most of the nutrients discharged from shrimp ponds originate from the artificial feed (Briggs \& Funge-Smith, 1994; Jackson et al., 2003), improving the water stability of feeds and reducing feed wastage has the potential to substantially reduce nutrient discharge loads (Burford, Jackson \& Preston, 2001).

There is considerable scope to reduce suspended solid and ammonium discharge loads by lining banks or entire ponds to reduce or eliminate erosion. Removing deposited sludge from ponds soon after it accumulates would also reduce the sediment load to the receiving environment as well as remineralization of nutrients (Hopkins, Sandifer \& Browdy, 1994; Burford \& Longmore, 2001). Passive sedimentation ponds can substantially reduce TSS levels but are less effective for total phosphorus (P) and N (Jackson, Preston, Burford \& Thompson, in press). Performance of treatment systems for farm discharge water may be improved by incorporating active nutrient removal strategies such as culture of mangrove forests, bivalves, macroalgae, fish and nitrifying bacteria (Jones \& Preston, 1999; Jones, Dennison \& Preston, 2001b; Kinne, Samocha, Jones \& Browdy, 2001; Páez-Osuna 2001). Reduction in discharges can also be achieved by recirculating water within farms, but this needs to be coupled with treatment systems (Browdy, Bratvold, Stokes \& McIntosh, 2001). 


\section{Future research}

This study focused principally on ecological processes in shrimp ponds and within the body of the creeks downstream of the shrimp farm. The role of the mangrove forests, tidal flats and their associated communities in processing nutrients from shrimp farm discharges was not assessed. The elevated $\delta^{15} \mathrm{~N}$ values in the mangrove leaves suggest that mangroves are assimilating nitrogen discharged from shrimp farms but the effects on mangrove forest health are unknown (Robertson \& Phillips, 1995). While the shrimp farm discharge had little effect on sediment processes within the creeks, this may not be the case in the adjacent tidal flats inhabited by benthic microalgae, meiofauna and macrofauna. Further study is warranted to assess possible impacts on these biota.

The effects of shrimp farm discharges on biodiversity are largely unknown. High anthropogenic nutrient loads have been linked with a reduction in phytoplankton species diversity and the development of nuisance blooms, with negative ramifications for the ecological health of coastal ecosystems (Smith et al., 1999; Alonso-Rodrígruez \& PáezOsuna 2003). In light of the key role that phytoplankton are playing in these ultratrophic environments, examination of phytoplankton species diversity is warranted.

Our study of ecological processes in ultratrophic ecosystems provides key information for future mathematical modeling. We have developed a quantitative understanding of the major processes and transformations, including the key rates of transformations and standing stocks of N, C and biota. This approach provides the basis for predictive models with the capacity to test scenarios for the impacts of aquaculture expansion and improvements in waste mitigation. Using these models, aquaculture can be placed in the context of other sources of nutrient loadings, i.e. agriculture and sewage effluent, as well as diffuse groundwater and atmospheric sources. The type and magnitude of the impacts can then be compared to allow ecological and economic tradeoffs to be explored. 


\section{Summary and conclusions}

This study is the first to link ecological processes in intensive shrimp ponds with impacts downstream. As a result, some key ecological processes and bioindicators were identified which have the potential for use in assessing the impacts of aquaculture. These findings are also applicable to other forms of feed-based, intensive aquaculture. Shrimp aquaculture discharges have different characteristics and impacts than other major sources of eutrophication in coastal waters, therefore management and regulation of the industry should reflect these differences. Ultimately, reduction in nutrient discharges is most likely to ensure the future sustainability of the industry, and an understanding of the ecological processes affected by aquaculture both in ponds and downstream provides an important step along this path. 


\section{Acknowledgments:}

This work was funded by the CRC for Aquaculture, Fisheries Research and Development Corporation grants No. 97/212 and 95/162, Australian Institute of Marine Science, The University of Queensland, CSIRO Marine Research and the Australian Prawn Farmers Association environmental levy. 


\section{References}

Alongi, D. M., Boto, K. G. \& Robertson, A. I. (1992). Nitrogen and phosphorus cycles. In: Tropical Mangrove Ecosystems. eds. A. I. Robertson \& D. M. Alongi, pp. 251292. American Geophysical Union, Washington, D.C.

Alongi, D. M., Ayukai, T., Brunskill, G. J., Clough, B. F. \& Wolanski, E. (1998). Sources, sinks and export of organic carbon through a tropical, semi-enclosed delta (Hinchinbrook Channel, Australia). Mangroves and Salt Marshes 2, 237-242.

Alonso-Rodríguez, R. \& Páez-Osuna, F. (2003). Nutrients, phytoplankton and harmful algal blooms in shrimp ponds: a review with special references to the situation in the Gulf of California. Aquaculture 219, 317-336.

Briggs, M. R. P. \& Funge-Smith, S. J. (1994). A nutrient budget of some intensive marine shrimp ponds in Thailand. Aquaculture and Fisheries Management. 25, 789811.

Browdy, C. L., Bratvold, D., Stokes, A. D. \& McIntosh, R. P. (2001). Perspectives on the application of closed shrimp culture systems. In: The New Wave, Proceedings of the Special Session on Sustainable Shrimp Culture, Aquaculture 2001. eds. C. L. Browdy and D. E. Jory, pp. 20-34. The World Aquaculture Society, Baton Rouge, USA.

Burford, M. A. (1997). Phytoplankton dynamics in shrimp ponds. Aquaculture Research 28, 351-360.

Burford, M. A. (2000). Fate and transformation of dietary nitrogen in penaeid prawn aquaculture ponds. PhD Thesis, University of Queensland, Australia, 162 pp.

Burford, M. A., Peterson, E. L., Baiano, J. C. F. \& Preston, N. P. (1998). Bacteria in shrimp pond sediments: their role in mineralizing nutrients and some suggested sampling strategies. Aquaculture Research 29, 843-849.

Burford, M. A. \& Glibert, P. M. (1999). Short-term nitrogen uptake and regeneration in early and late growth phase shrimp ponds. Aquaculture Research 30, 1-13. 
Burford. M. A., Jackson, C. J. \& Preston, N. P. (2001). Reducing nitrogen waste from shrimp farming: an integrated approach. In: The New Wave, Proceedings of the Special Session on Sustainable Shrimp Culture, Aquaculture 2001. eds. C. L. Browdy and D. E. Jory, pp. 35-43. The World Aquaculture Society, Baton Rouge, USA.

Burford, M. A. \& Longmore, A.R. (2001). High ammonium production from sediments in hypereutrophic shrimp ponds. Marine Ecology Progress Series 224, 187-195.

Burford, M. A. \& Williams, K. C. (2001). The fate of nitrogenous waste from shrimp feeding. Aquaculture 198, 79-93.

Cloern, J. E. (2001). Our evolving conceptual model of the coastal eutrophication problem. Marine Ecology Progress Series 210, 223-253.

Coman, F. E., Connolly, R. M. \& Preston, N. P. (2003). Zooplankton and epibenthic fauna in shrimp ponds - factors influencing assemblage dynamics. Aquaculture Research, 34, 359-371.

Costanzo, S. D. (2001). Development of indicators for assessing and monitoring nutrient influences in coastal waters. PhD Thesis, University of Queensland, Australia.

Costanzo, S. D., O’Donohue, M. J., Dennison, W. C., Loneragan, N. R. \& Thomas, M. (2001). A new approach for detecting and mapping sewage impacts. Marine Pollution Bulletin, 42, 149-156.

Eyre, B. (1993). Nutrients in the sediment of a tropical north-eastern Australian estuary, catchment and nearshore coastal zone. Australian Journal of Marine and Freshwater Research. 44, 845-866.

Gross, A., Boyd, C. E. \& Wood, C. W. (1999). Ammonia volatilization from freshwater fish ponds. Journal of Environmental Quality 28, 793-797.

Hargreaves, J. A. (1998). Nitrogen biogeochemistry of aquaculture ponds. Aquaculture $166,181-212$. 
Heaton, T. H. E. (1986). Isotopic studies of nitrogen pollution in the hydrosphere and atmosphere: a review. Chemical Ecology, 59, 87-102.

Hopkins, J. S., Sandifer, P. A. \& Browdy, C. L. (1994). Sludge management in intensive pond culture of shrimp: Effect of management regime on water quality, sludge characteristics, N extinction, and shrimp production. Aquacultural Engineering 13, $11-30$.

Jackson, C., Preston, N., Thompson, P. \& Burford, M. (2003). Nitrogen budget and effluent nitrogen components at an intensive shrimp farm.

Aquaculture, 218, 397-411.

Jackson, C.J., Preston, N.P., Burford, M.A. \& Thompson, P.T. (200...).

Managing the sustainable development of shrimp farming in Australia: the performance of treatment ponds. Aquaculture, in press.

Jones, A. B. \& Preston, N. P. (1999). Oyster filtration of shrimp farm effluent, the effects on water quality. Aquaculture Research 30, 51-57.

Jones, A. B., O'Donohue, M. J., Udy, J. \& Dennison, W. C. (2001a). Assessing ecological impacts of shrimp and sewage effluent: biological indicators with standard water quality analyses. Estuarine, Coastal and Shelf Science 52, 91-109.

Jones, A. B., Dennison, W. C. \& Preston, N. P. (2001b). Integrating treatment of shrimp effluent by sedimentation, oyster filtration and macroalgal absorption: a laboratory scale study. Aquaculture 193, 155-178.

Jory, D. E., Cabrera, T. R., Dugger, D. M., Fegan, D., Lee, P. G., Lawrence, A. L., Jackson, C. J., McIntosh, R. P. \& Castañeda, J. (2001). A global review of shrimp feed management: Status and perspectives. In: The New Wave, Proceedings of the Special Session on Sustainable Shrimp Culture, Aquaculture 2001. eds. C. L. Browdy \& D. E. Jory, pp. 104-152. The World Aquaculture Society, Baton Rouge, USA. 
Kinne, P. N., Samocha, T. M., Jones, E. R. \& Browdy, C. L. (2001). Characterization of intensive shrimp pond effluent and preliminary studies on biofiltration. North American Journal of Aquaculture 63, 25-33.

McKinnon, A. D. \& Klumpp, D. W. (1998). Mangrove zooplankton of North Queensland, Australia I. Plankton community structure and environment. Hydrobiologia 362, 127-143.

McKinnon, A. D., Trott, L. A., Alongi, D. M. \& Davidson, A. (2002a). Water column production and nutrient characteristics in mangrove creeks receiving shrimp farm effluent. Aquaculture Research 33, 55-73

McKinnon, A. D., Trott, L. A., Cappo, M., Miller, D. K., Speare, P. \& Davidson, A. (2002b). The trophic fate of shrimp farm effluent in mangrove creeks of North Queensland, Australia. Estuarine, Coastal and Shelf Science 55, 655-671

Milton, D. A., Blaber, S. J. M. \& Rawlinson, N. J. F. (1990). Diet and prey selection of six species of tuna baitfish in three coral reef lagoons in the Solomon Islands. Journal of Fish Biology 37, 205-224.

Milton, D. A., Blaber, S. J. M. \& Rawlinson, N. J. F. (1994). Diet, prey selection and their energetic relationship to reproduction in the tropical herring Herklotsichthys quadrimaculatus in Kiribati, central Pacific. Marine Ecology Progress Series 103, 239-250

Naylor, R. L., Goldburg, R. J., Mooney, H., Beveridge, M., Clay, J., Folke, C., Kautsky, N., Lubchenco, J., Primavera, J. \& Williams, M. (1998). Nature’s subsidies to shrimp and salmon farming. Science 282, 883-884.

Nixon, S. W. (1995). Coastal marine eutrophication: a definition, social causes and future concerns. Ophelia 41, 199-219.

Páez-Osuna, F. (2001). The environmental impact of shrimp aquaculture: Causes, effects and mitigating alternatives. Environmental Management 28, 131-140. 
Peterson, E. L. (1999). Benthic shear stress and sediment condition. Aquacultural Engineering 21, 81-111.

Preston, N. P., Rothlisberg, P. C., Burford, M. A. \& Jackson, C. J. (2001). The Environmental Management of Shrimp Farming in Australia. Report prepared under the World Bank, NACA, WWF and FAO Consortium Program on Shrimp Farming and the Environment. Work in Progress for Public Discussion. Network of Aquaculture Centres in Asia-Pacific (NACA) Bangkok, Thailand, 9pp.

Preston, N. P., Coman, F. E. \& Fry, V. M. (2003) Shrimp pond zooplankton dynamics and the optimization of sampling effort. Aquaculture Research 34, 373-381.

Rivera-Monroy, V. H. \& Twilley, R. R. (1996). The relative role of denitrification and immobilization in the fate of inorganic nitrogen in mangrove sediments (Terminos Lagoon, Mexico). Limnology and Oceanography 41, 284-296.

Robertson, A. I. \& Blaber, S. J. M. (1992). Plankton, epibenthos, and fish communities. In: Tropical Mangrove Ecosystems, eds. A. I. Robertson \& D. M. Alongi, pp. 173224, American Geophysical Union, Washington, D.C.

Robertson, A. I. \& Phillips, M. J. (1995). Mangroves as filters of shrimp pond effluents: predictions and biogeochemical research needs. Hydrobiologia 295, 311-321.

Seitzinger, S. (1988). Denitrification in freshwater and coastal marine ecosystems: Ecological and geochemical significance. Limnology and Oceanography 33, 702-724.

Smith, V. H., Tilman, G. D. \& Nekola, J. C. (1999). Eutrophication: impacts of excess nutrient inputs on freshwater, marine and terrestrial ecosystems. Environmental Pollution 100, 179-196.

Trott, L. A. \& Alongi, D. M. (1999). Variability in surface water chemistry and phytoplankton biomass in two tropical, tidally-dominated mangrove waterways. Marine and Freshwater Research 50, 451-457. 
Trott, L. A. \& Alongi, D. M. (2000). The impact of shrimp pond effluent on water quality and phytoplankton biomass in a tropical mangrove estuary. Marine Pollution Bulletin 40, 947-951.

Trott, L. A. \& Alongi, D. M. (2001). Quantifying and predicting the impact of prawn effluent on the assimilative capacity of coastal waterways. FRDC 97/212 Final Report, Fishing Industry Research and Development Corporation, Canberra, Australia.

Trott, L. A., McKinnon, A.D., Alongi, D. M., Davidson, A. \& Burford, M. A. (200...) Carbon and nitrogen processes in a mangrove creek receiving shrimp farm effluent. Estuarine, Coastal and Shelf Science, in press.

Wolanski, E. (1992). Hydrodynamics of mangrove swamps and their coastal waters. Hydrobiologia 247, 141-161.

Wolanski, E., Jones, M. \& Bunt, J. (1980). Hydrodynamics of a tidal creek-mangrove swamp system. Australian Journal of Marine and Freshwater Research, 31, 431-450.

Wolanski, E., Spagnol, S., Thomas, S., Moore, K., Alongi, D. M., Trott, L. A. \& Davidson, A. (2000). Modeling and visualizing the fate of shrimp pond effluent in a mangrove-fringed tidal creek. Estuarine, Coastal and Shelf Science 50, 85-97.

Ziemann, D. A., Walsh, W. A., Saphore, E. G. \& Fulton-Bennett, K. (1992). A survey of water quality characteristics of effluent from Hawaiian aquaculture facilities. Journal of the World Aquaculture Society 23, 180-191. 


\section{Figure Legend}

Figure 1: Map of the study areas at Farms 1 and 2 in northern Queensland, Australia. Filled circles show sampling locations. Muddy and Pig Creeks received shrimp pond discharges. Sandfly and Morris Creeks were control creeks.

Figure 2: Pools (mmol m${ }^{-2}$ ) and fluxes $\left(\mathrm{mmol} \mathrm{m}^{-2} \mathrm{~d}^{-1}\right)$ of $\mathrm{N}$ in last season shrimp ponds, 0-2 km downstream (during shrimp farm discharges) and $>2 \mathrm{~km}$ downstream. Data sourced from Tables 3, 4, 5 and 6. $\mathrm{PN}=$ particulate $\mathrm{N}, \mathrm{NH}_{3}=$ total ammonia, $\mathrm{DON}=$ dissolved organic $\mathrm{N}, \mathrm{N}_{2}=$ nitrogen gas.

Figure 3: Pools $\left(\mathrm{mmol} \mathrm{m}^{-2}\right)$ and fluxes $\left(\mathrm{mmol} \mathrm{m}^{-2} \mathrm{~d}^{-1}\right)$ of $\mathrm{P}$ in last season shrimp ponds, 0-2 km downstream (during shrimp farm discharges) and $>2 \mathrm{~km}$ downstream. Data sourced from Tables 3, 4, 5 and 6. $\mathrm{PP}=$ particulate $\mathrm{P}, \mathrm{PO}_{4}=$ phosphate, $\mathrm{DOP}=$ dissolved organic P. 
Table 1. Physical descriptions of the two creeks, Muddy and Pig Creeks, receiving shrimp farm discharges, and the control creeks, Sandfly and Morris Creeks, where the study was conducted in north Queensland, Australia.

\begin{tabular}{lrccc}
\hline & \multicolumn{1}{c}{ Farm 1 } & & \multicolumn{1}{c}{ Farm 2 } & \\
& Muddy Ck & Sandfly Ck & Pig Creek Morris Ck \\
\hline Length (m) & 6,904 & 4,400 & 2,228 & 4,200 \\
Length ultratrophic zone (m) & 1,308 & 966 & & \\
Total surface area $\left(\mathrm{m}^{2}\right)$ & 100,000 & 34,050 & & \\
Surface area of ultratrophic & 9,930 & 12,996 & & \\
zone $\left(\mathrm{m}^{2}\right)$ & & & & \\
Tidal exchange $\left(\mathrm{m}^{3} \mathrm{yr}^{-1}\right)$ & $10^{7}$ & $10^{7}$ & & \\
Tidal range $(\mathrm{m})$ & $0.0-3.0$ & $0.0-3.0$ & $0.1-3.5$ & \\
Farm discharge volume & $3.5-9.8$ & 2.8 & & \\
$\left(106 \mathrm{~m}^{3} \mathrm{y}^{-1}\right.$ ) & & & & \\
\end{tabular}


Table 2: Parameters measured in shrimp ponds, the 1 to $2 \mathrm{~km}$ downstream, and further downstream in the mangrove-lined creek.

\begin{tabular}{|c|c|c|}
\hline Parameter & Method & Reference \\
\hline \multicolumn{3}{|l|}{ Shrimp ponds } \\
\hline \multicolumn{3}{|l|}{ Water column } \\
\hline Nutrients, chlorophyll $a$ & Colorimetric & \\
\hline \multirow[t]{3}{*}{ Quantification of biota } & Microscopic counts & Burford (1997) \\
\hline & & Preston et al. (in press) \\
\hline & & Coman et al. (in press) \\
\hline Primary productivity & ${ }^{14} \mathrm{C}$ incubations & Burford (1997) \\
\hline \multirow[t]{2}{*}{$\mathrm{NH}_{4}^{+}$uptake/regeneration } & ${ }^{15} \mathrm{~N}$ labelling & Burford \& Glibert (1999) \\
\hline & & Burford (2000) \\
\hline \multirow[t]{2}{*}{ DON production/consumption } & ${ }^{15} \mathrm{~N}$ labelling/utilization studies & Burford \& Williams (2001) \\
\hline & & Burford \& Glibert (2000) \\
\hline Shrimp excretion & Physiological studies & Burford \& Williams (2001) \\
\hline \multicolumn{3}{|l|}{ Sediment } \\
\hline Nutrients & Digestion/colorimetric & Burford et al. (1998) \\
\hline Nutrient, $\mathrm{O}_{2}, \mathrm{CO}_{2}$ fluxes & Benthic chambers & Burford \& Longmore (2001) \\
\hline Denitrification & Acetylene block & Burford \& Longmore (2001) \\
\hline \multicolumn{3}{|l|}{ Shrimp farm discharges } \\
\hline Water volume & Doppler flow dataloggers & Jackson et al. (2003) \\
\hline Nutrients & Colorimetric & Jackson et al. (2003) \\
\hline \multicolumn{3}{|l|}{ Creeks } \\
\hline \multicolumn{3}{|l|}{ Water column } \\
\hline Water flow characteristics & Current meter & Wolanski et al. (1980, 2000) \\
\hline Nutrients, chlorophyll $a$ & Colorimetric & Trott \& Alongi (2001) \\
\hline Quantification of biota & Microscopic counts & McKinnon et al. (2002b) \\
\hline $\mathrm{NH}_{4}^{+}$uptake/regeneration & ${ }^{15} \mathrm{~N}$ labelling & Trott \& Alongi (2001) \\
\hline Primary production & ${ }^{14} \mathrm{C}$ incubations & McKinnon et al. (2002a) \\
\hline Bacterial production & ${ }^{3} \mathrm{H}$ incubations & McKinnon et al. (2002a) \\
\hline Zooplankton grazing & Dilution experiments & McKinnon et al. (2002b) \\
\hline Fish grazing & Gut contents & McKinnon et al. (2002b) \\
\hline \multicolumn{3}{|l|}{ Sediment } \\
\hline Nutrient, $\mathrm{O}_{2}, \mathrm{CO}_{2}$ fluxes & Benthic chambers & Trott \& Alongi (2001) \\
\hline Denitrification & $\mathrm{N}_{2}$ gas flux & Trott \& Alongi (2001) \\
\hline \multicolumn{3}{|l|}{ Bioindicators } \\
\hline Stable isotopes - mangroves & Mass spectrometer & Costanzo (2001) \\
\hline Stable isotopes - macroalgae & $4 \mathrm{~d}$ incubation, mass spectro. & Costanzo (2001) \\
\hline Phytoplankton bioassay & $7 \mathrm{~d}$ incubation \pm nutrients & Costanzo (2001) \\
\hline
\end{tabular}


Table 3. Mean ( \pm SD) nutrient, suspended solids and chlorophyll a concentrations, and light availability in the water column of shrimp ponds at a range of farms early (first 1 to 2 months) and late (4 to 5 months) in the growth season.

\begin{tabular}{|c|c|c|c|c|c|}
\hline \multirow{2}{*}{$\frac{\text { Parameter }}{\mu \mathrm{M}}$} & farms & \multicolumn{2}{|c|}{ Number of } & occ. Mean (SD) & \multirow[t]{2}{*}{ References } \\
\hline & & & & & \\
\hline \multicolumn{6}{|l|}{ Early growth season } \\
\hline Ammonium-N & 2 & 11 & 46 & $8.6(8.4)$ & Burford (1997); Burford \& Glibert (1997); Mathieu (unpubl. Data) \\
\hline Nitrate/nitrite-N & 2 & 5 & 5 & $2.7(3.7)$ & Burford (1997); Burford \& Glibert (1997) \\
\hline Phosphate-P & 2 & 11 & 45 & $0.8(0.8)$ & Burford (1997); Burford \& Glibert (1997); Mathieu (unpubl. Data) \\
\hline Chl $a\left(\mu \mathrm{g} \mathrm{L}^{-1}\right)$ & 2 & 11 & 47 & $17.0(14.9)$ & Burford (1997); Burford \& Glibert (1997); Mathieu (unpubl. Data) \\
\hline TSS (mg L $\left.{ }^{-1}\right)$ & 1 & 2 & 4 & $17.4(2.1)$ & Burford (1997) \\
\hline \multicolumn{6}{|l|}{ Late growth season } \\
\hline Ammonium-N & 4 & 15 & 65 & $22.0(31.7)$ & $\begin{array}{l}\text { Burford (1997); Preston et al. (2000); Burford \& Longmore (2001); Burford } \\
\text { \& Lorenzen (in press); Mathieu (unpubl. Data); Jackson (unpubl. Data) }\end{array}$ \\
\hline Nitrate/nitrite-N & 1 & 5 & 21 & $3.6(4.6)$ & Burford (1997); Burford \& Lorenzen (in press); Jackson (unpubl. Data) \\
\hline Phosphate-P & 1 & 9 & 35 & $0.1(0.2)$ & Burford (1997); Burford \& Lorenzen (in press); Mathieu (unpubl. Data) \\
\hline DON & 2 & 4 & 18 & $74.0(23.7)$ & Preston et al. (2000); Jackson (unpubl. Data) \\
\hline Total N & 2 & 2 & 17 & $231.0(36.7)$ & Preston et al. (2000); Jackson (unpubl. Data) \\
\hline Total P & 1 & 2 & 21 & $11.7(0.8)$ & Preston et al. (2000); Jackson (unpubl. Data) \\
\hline Molar N:P & & & & 19.7 & \\
\hline Chl $a\left(\mu \mathrm{g} \mathrm{L}^{-1}\right)$ & 4 & 14 & 65 & $167.7(93.8)$ & $\begin{array}{l}\text { Burford (1997); Preston et al. (2000); Burford \& Longmore (2001); Burford } \\
\text { \& Lorenzen (in press); Mathieu (unpubl. Data); Jackson (unpubl. Data) }\end{array}$ \\
\hline TSS (mg L $\left.{ }^{-1}\right)$ & 2 & 7 & 47 & $48.1(24.0)$ & Preston et al. (2000); Jackson (unpubl. Data) \\
\hline Extinction coefficient (m & $\left.\mathrm{n}^{-1}\right) 1$ & 1 & 6 & $3.8(0.8)$ & Burford (1997) \\
\hline
\end{tabular}


Table 4. Mean ( \pm SD) transformations of N, P, C and oxygen during the early and late growth seasons for a number of farms, shrimp ponds and sampling occasions. $\mathrm{wc}=$ water column.

\begin{tabular}{|c|c|c|c|c|c|}
\hline Parameter & $\begin{array}{r}N \\
\text { farms }\end{array}$ & $\begin{array}{c}\text { mber of } \\
\text { ponds }\end{array}$ & Sampling occ. & Mean (SD) & References \\
\hline \multicolumn{6}{|l|}{$\begin{array}{l}\text { Early growth season } \\
N \mathrm{mmol} \mathrm{m} \mathrm{m}^{-2} \mathrm{~d}^{-1}\end{array}$} \\
\hline $\mathrm{NH}_{4}$ uptake & 1 & 3 & 6 & $26.0(2.0)$ & Burford \& Glibert (1999) \\
\hline $\mathrm{NH}_{4}$ wc regeneration & 1 & 3 & 6 & $27.0(0.2)$ & Burford \& Glibert (1999) \\
\hline \multicolumn{6}{|l|}{$\begin{array}{l}\text { Late growth season } \\
N \mathrm{mmol} \mathrm{m} \mathrm{m}^{-2} d^{-1}\end{array}$} \\
\hline $\mathrm{NH}_{4}$ uptake & 2 & 6 & 9 & $110.0(9.7)$ & Burford \& Glibert (1999); Burford (2000) \\
\hline $\mathrm{NH}_{4}$ wc regeneration & 1 & 3 & 6 & $82.7(10.0)$ & Burford \& Glibert (1999) \\
\hline Sediment $\mathrm{NH}_{4}$ flux & 3 & 5 & 5 & $27.8(4.9)$ & Burford \& Longmore (2001) \\
\hline Sediment NOx flux & 3 & 5 & 5 & -0.8 & Burford \& Longmore (2001) \\
\hline $\begin{array}{l}\text { Denitrification } \\
C \mathrm{mmol} \mathrm{m} \mathrm{m}^{-2} \mathrm{~d}^{-1}\end{array}$ & 3 & 5 & 5 & $2.0(5.7)$ & Burford \& Longmore (2001) \\
\hline Primary production & 1 & 1 & 6 & $200.0(46.0)$ & Burford (1997) \\
\hline $\begin{array}{l}\text { Benthic respiration } \\
P \mathrm{mmol} \mathrm{m} \mathrm{m}^{-2} \mathrm{~d}^{-1}\end{array}$ & 3 & 5 & 5 & $217.5(36.9)$ & Burford \& Longmore (2001) \\
\hline $\begin{array}{l}\text { Sediment } \mathrm{PO}_{4} \text { flux } \\
\mathrm{O}_{2} \mathrm{mmol} \mathrm{m}^{-2} d^{-1}\end{array}$ & 3 & 5 & 5 & $0.3(0.1)$ & Burford \& Longmore (2001) \\
\hline Sediment oxygen demand & 3 & 5 & 5 & $90.2(6.6)$ & Burford \& Longmore (2001) \\
\hline
\end{tabular}


Table 5: Mean ( \pm SD) nutrient, suspended solids and chlorophyll $a$ concentrations in the water column of the creeks (Muddy and Pig Creeks) 0 to $2 \mathrm{~km}$ from the shrimp farms during periods of discharge and no discharge, and $>2 \mathrm{~km}$ downstream from the shrimp farms in Muddy and Pig Creeks combined with data from the control creeks, Morris and Sandfly Creeks.

\begin{tabular}{|c|c|c|c|c|c|c|}
\hline Parameter $(\mu \mathrm{M})$ & \# creeks & \#locations & Occasions & $\mathbf{N}$ & Mean & SD \\
\hline \multicolumn{7}{|l|}{ 0-2 km from shrimp farm } \\
\hline \multicolumn{7}{|l|}{ Water discharge period } \\
\hline Ammonium & 2 & 2 & 13 & 74 & 5.0 & 5.8 \\
\hline Nitrate/nitrite & 2 & 2 & 13 & 74 & 1.1 & 2.1 \\
\hline DON & 2 & 2 & 13 & 73 & 11.7 & 10.4 \\
\hline Inorganic Phosphate & 2 & 2 & 13 & 74 & 0.1 & 0.2 \\
\hline Organic Phosphate & 2 & 2 & 13 & 74 & 0.5 & 0.2 \\
\hline Dissolved organic C & 2 & 2 & 13 & 68 & 358.2 & 93.3 \\
\hline Particulate N & 2 & 2 & 13 & 85 & 47.6 & 30.4 \\
\hline Particulate P & 2 & 2 & 13 & 95 & 3.5 & 2.1 \\
\hline Particulate C & 2 & 2 & 13 & 86 & 327.1 & 218.3 \\
\hline Molar C:N & 2 & 2 & 13 & 84 & 7.0 & 1.2 \\
\hline Molar N:P & 2 & 2 & 13 & 85 & 14.6 & 6.6 \\
\hline Chlorophyll $a\left(\mu \mathrm{g} \mathrm{L}^{-1}\right)$ & 2 & 2 & 13 & 54 & 43.4 & 39.9 \\
\hline TSS $\left(\mathrm{mg} \mathrm{L}^{-1}\right)$ & 2 & 2 & 13 & 54 & 53.0 & 19.3 \\
\hline \multicolumn{7}{|l|}{ Non discharge period } \\
\hline Ammonium & 2 & 2 & 5 & 17 & 4.2 & 3.8 \\
\hline Nitrate/nitrite & 2 & 2 & 5 & 17 & 3.0 & 1.9 \\
\hline DON & 2 & 2 & 5 & 17 & 14.2 & 7.0 \\
\hline Inorganic Phosphate & 2 & 2 & 5 & 17 & 0.4 & 0.5 \\
\hline Organic Phosphate & 2 & 2 & 5 & 17 & 0.4 & 0.3 \\
\hline Dissolved organic C & 2 & 2 & 5 & 15 & 302.9 & 153.5 \\
\hline Particulate N & 2 & 2 & 5 & 11 & 23.1 & 24.2 \\
\hline Particulate P & 2 & 2 & 5 & 13 & 1.8 & 1.6 \\
\hline Particulate C & 2 & 2 & 5 & 11 & 198.4 & 189.8 \\
\hline Molar C:N & 2 & 2 & 5 & 11 & 10.0 & 1.6 \\
\hline Molar N:P & 2 & 2 & 5 & 10 & 15.1 & 4.7 \\
\hline Chlorophyll $a\left(\mu \mathrm{g} \mathrm{L}^{-1}\right)$ & 2 & 2 & 5 & 69 & 2.3 & 2.9 \\
\hline TSS $\left(\mathrm{mg} \mathrm{L}^{-1}\right)$ & 2 & 2 & 5 & 65 & 21.8 & 13.2 \\
\hline \multicolumn{7}{|c|}{$>2 \mathrm{~km}$ downstream from shrimp farm } \\
\hline Ammonium & 5 & 8 & 39 & 117 & 1.1 & 1.2 \\
\hline Nitrate/nitrite & 5 & 8 & 39 & 117 & 0.8 & 1.2 \\
\hline DON & 5 & 8 & 39 & 117 & 10.3 & 8.4 \\
\hline Inorganic Phosphate & 5 & 8 & 39 & 117 & 0.1 & 0.2 \\
\hline Organic Phosphate & 5 & 8 & 39 & 117 & 0.2 & 0.2 \\
\hline Dissolved organic C & 5 & 8 & 31 & 93 & 155.7 & 65.2 \\
\hline Particulate N & 5 & 8 & 36 & 109 & 6.9 & 2.6 \\
\hline Particulate P & 5 & 8 & 41 & 132 & 0.7 & 0.7 \\
\hline Particulate C & 5 & 8 & 36 & 109 & 63.9 & 31.8 \\
\hline Molar C:N & 5 & 8 & 36 & 109 & 8.8 & 2.0 \\
\hline Molar N:P & 5 & 8 & 35 & 105 & 14.0 & 6.5 \\
\hline Chl $a\left(\mu \mathrm{g} \mathrm{L}^{-1}\right)$ & 5 & 8 & 55 & 164 & 2.2 & 2.1 \\
\hline TSS (mg L $\left.{ }^{-1}\right)$ & 5 & 8 & 51 & 153 & 17.2 & 12.1 \\
\hline
\end{tabular}


Table 6: Mean $( \pm$ SD) N, P, C and oxygen transformation processes in Muddy and Pig Creeks 0-2 $\mathrm{km}$ downstream of a shrimp farm, and combined data for $>2 \mathrm{~km}$ downstream in Pig and Muddy Creeks plus the control creeks, Sandfly and Morris Creeks. \# creeks = farms 1 and 2, \# locations $=$ sites in creeks, Occasions $=$ sampling occasions, $\mathrm{N}=$ total number of samples collected from all sampling trips, $\mathrm{W} / \mathrm{C}=$ water column, $\mathrm{NH}_{4}=$ ammonium, $\mathrm{NO}_{\mathrm{x}}=$ oxides of $\mathrm{N}, \mathrm{DON}=$ dissolved organic N.

\begin{tabular}{|c|c|c|c|c|c|c|}
\hline Processes & \# creeks & \#locations & Occasions & $\mathbf{N}$ & Mean & SD \\
\hline \multicolumn{7}{|l|}{ 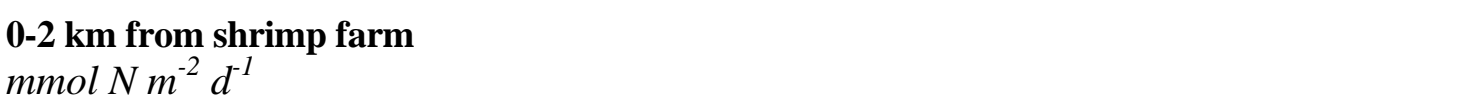 } \\
\hline W/C NH 4 uptake & 1 & 2 & 3 & 7 & 32.9 & 34.1 \\
\hline Sediment $\mathrm{NH}_{4}$ flux & 1 & 2 & 2 & 24 & 2.07 & 3.27 \\
\hline Sediment $\mathrm{NO}_{\mathrm{x}}$ flux & 1 & 2 & 2 & 24 & -0.07 & 0.20 \\
\hline Sediment DON flux & 1 & 2 & 2 & 24 & 0.30 & 5.80 \\
\hline $\begin{array}{l}\text { Sediment denitrification } \\
\mathrm{mmol} \mathrm{C} \mathrm{m}^{-2} d^{-1}\end{array}$ & 1 & 2 & 4 & 28 & 1.37 & 1.58 \\
\hline Sediment respiration & 1 & 2 & 2 & 24 & 0.01 & 0.01 \\
\hline Primary production & 2 & 2 & 4 & 4 & 276.5 & 149.1 \\
\hline $\begin{array}{l}\text { W/C bacterial production } \\
\mathrm{mmol} \mathrm{P} \mathrm{m}^{-2} d^{-1}\end{array}$ & 2 & 2 & 4 & 4 & 39.4 & 18.2 \\
\hline Sediment phosphate & 1 & 2 & 2 & 24 & -0.06 & 0.10 \\
\hline $\begin{array}{l}\text { Sediment Diss. Org. } \mathrm{P} \\
\mathrm{mmol} \mathrm{O} \mathrm{m}^{-2} d^{-1}\end{array}$ & 1 & 2 & 2 & 24 & -0.29 & 0.80 \\
\hline Sediment oxygen demand & 1 & 2 & 2 & 24 & -0.03 & 0.02 \\
\hline \%Sedimentation of w/c C & 1 & 2 & 3 & 15 & 14.5 & 3.9 \\
\hline \%Sedimentation of w/c N & 1 & 2 & 3 & 15 & 12.4 & 2.2 \\
\hline \%Sedimentation of w/c P & 1 & 2 & 3 & 15 & 14.2 & 2.7 \\
\hline
\end{tabular}

$>\mathbf{2} \mathbf{~ k m}$ downstream from shrimp farm mmol $\mathrm{N} \mathrm{m}^{-2} d^{-1}$

$\mathrm{W} / \mathrm{C} \mathrm{NH} \mathrm{N}_{4}$ uptake

Sediment $\mathrm{NH}_{4}$ flux

Sediment NOx flux

Sediment DON flux

Sediment denitrification

mmol C m${ }^{-2} d^{-1}$

Sediment respiration

Primary production

W/C bacterial production

mmol $P m^{-2} d^{-1}$

Sediment phosphate

Sediment Diss. Org. P

mmol $O m^{-2} d^{-1}$

Sediment oxygen demand

\%Sedimentation of w/c C

\%Sedimentation of w/c N

\%Sedimentation of w/c P

$\begin{array}{rrrrrr}1 & 4 & 2 & 10 & 27.1 & 13.1 \\ 1 & 2 & 2 & 24 & 0.90 & 2.53 \\ 1 & 2 & 2 & 24 & -0.02 & 0.18 \\ 1 & 2 & 2 & 24 & -0.65 & 2.93 \\ 1 & 2 & 4 & 28 & 1.61 & 0.31 \\ & & & & & \\ 1 & 2 & 2 & 24 & 0.01 & 0.01 \\ 4 & 4 & 12 & 12 & 39.1 & 25.9 \\ 4 & 4 & 12 & 12 & 16.3 & 10.8 \\ & & & & & \\ 1 & 2 & 2 & 24 & -0.02 & 0.08 \\ 1 & 2 & 2 & 24 & -0.09 & 0.37 \\ & & & & & \\ 1 & 2 & 2 & 24 & -0.03 & 0.02 \\ & & & & & \\ 1 & 2 & 3 & 15 & 6.9 & 1.7 \\ 1 & 2 & 3 & 15 & 34.9 & 1.2 \\ 1 & 2 & 3 & 15 & 50.0 & 0.2\end{array}$


Table 7. Stable isotopes in mangroves and macroalgae (mean \pm SD), and phytoplankton response index (PRI, mean \pm SD) in mangrove creek (Pig Creek, Farm 2). PRI value reflects the response to nitrate, ammonium, phosphate and silicate.

\begin{tabular}{|c|c|c|c|c|c|c|c|c|}
\hline \multirow{2}{*}{$\begin{array}{l}\text { Pond } \\
\text { Growth phase }\end{array}$} & \multirow[t]{2}{*}{ Mangrove Creek } & \multirow[t]{2}{*}{ \#creeks } & \multirow{2}{*}{\multicolumn{2}{|c|}{ \# locations \# Occasions }} & \multirow[t]{2}{*}{$\mathbf{N}$} & \multicolumn{2}{|c|}{$\delta^{15} \mathrm{~N}(\%)$} & \multirow[t]{2}{*}{ PRI } \\
\hline & & & & & & Macroalgae & Mangroves & \\
\hline \multirow[t]{3}{*}{ Production } & 0-2 km discharge creek & 1 & 2 & 1 & 1 & $4.8(0.6)$ & $6.6(2.1)$ & $1.7(2.3)$ \\
\hline & $>2 \mathrm{~km}$ downstream & 1 & 2 & 1 & 1 & $4.7(0)$ & $2.7(1.3)$ & $2.6(3.3)$ \\
\hline & Control creek & 1 & 3 & 1 & 1 & $3.3(0.7)$ & $2.5(0.4)$ & $4.3(2.5)$ \\
\hline Harvesting & 0-2 km discharge creek & 1 & 2 & 1 & 1 & $5.5(0.2)$ & $7.5(2.8)$ & $0.9(1.2)$ \\
\hline \multirow[t]{2}{*}{ Season } & $>2 \mathrm{~km}$ downstream & 1 & 2 & 1 & 1 & $4.7(0.1)$ & 3.7 (1.3) & $3.3(1.3)$ \\
\hline & Control creek & 1 & 3 & 1 & 1 & $2.8(0)$ & $3.2(0.8)$ & 27.0 (11.9) \\
\hline \multirow[t]{3}{*}{ Empty ponds } & 0-2 km discharge creek & 1 & 2 & 1 & 1 & $4.4(0.4)$ & $5.7(2.1)$ & $2.7(0.0)$ \\
\hline & $>2 \mathrm{~km}$ downstream & 1 & 2 & 1 & 1 & $3.1(0.3)$ & $2.9(0.7)$ & $3.6(0.3)$ \\
\hline & Control creek & 1 & 2 & 1 & 1 & $2.9(0.2)$ & $0.9(0.9)$ & $2.9(0.8)$ \\
\hline
\end{tabular}


Fig. 1

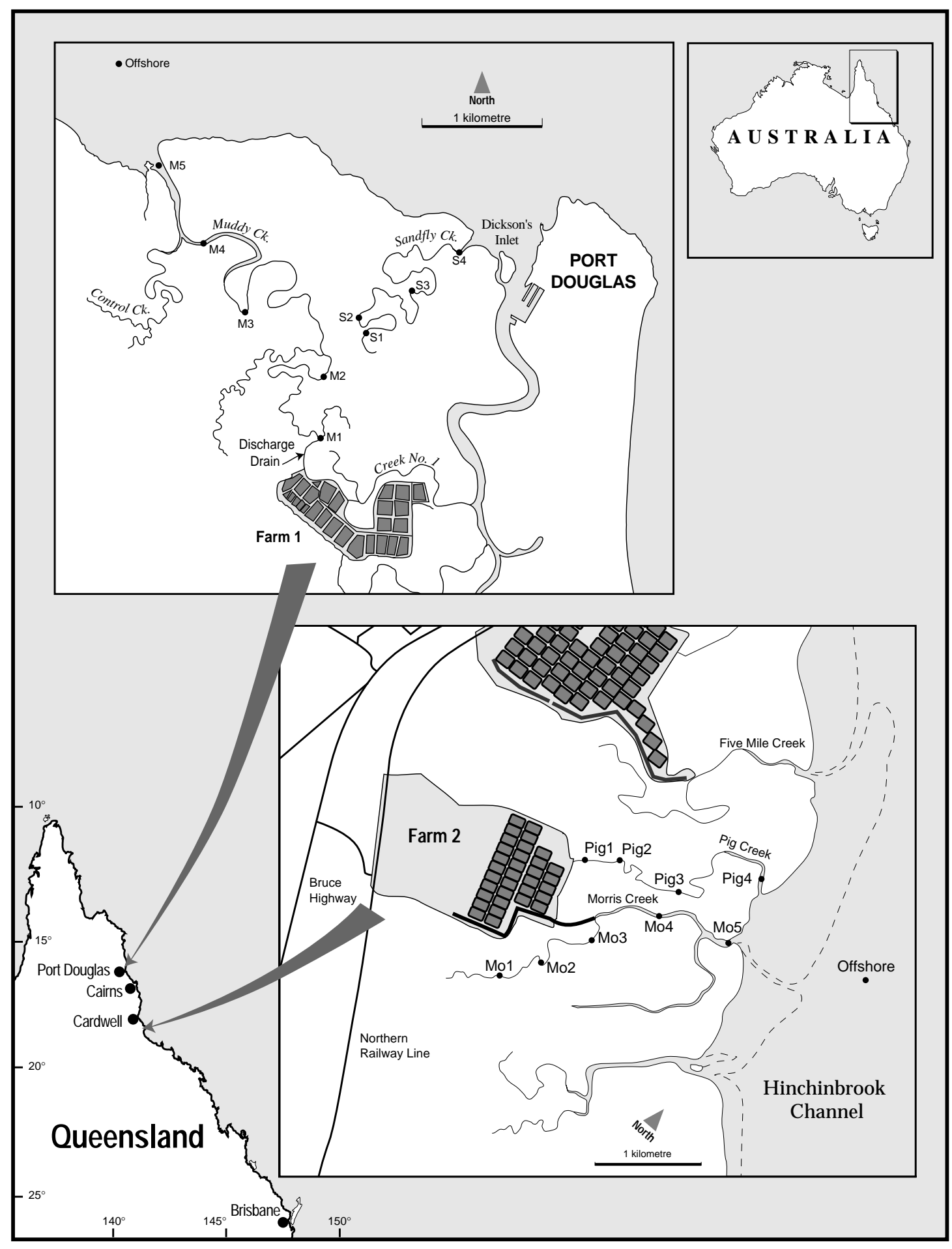




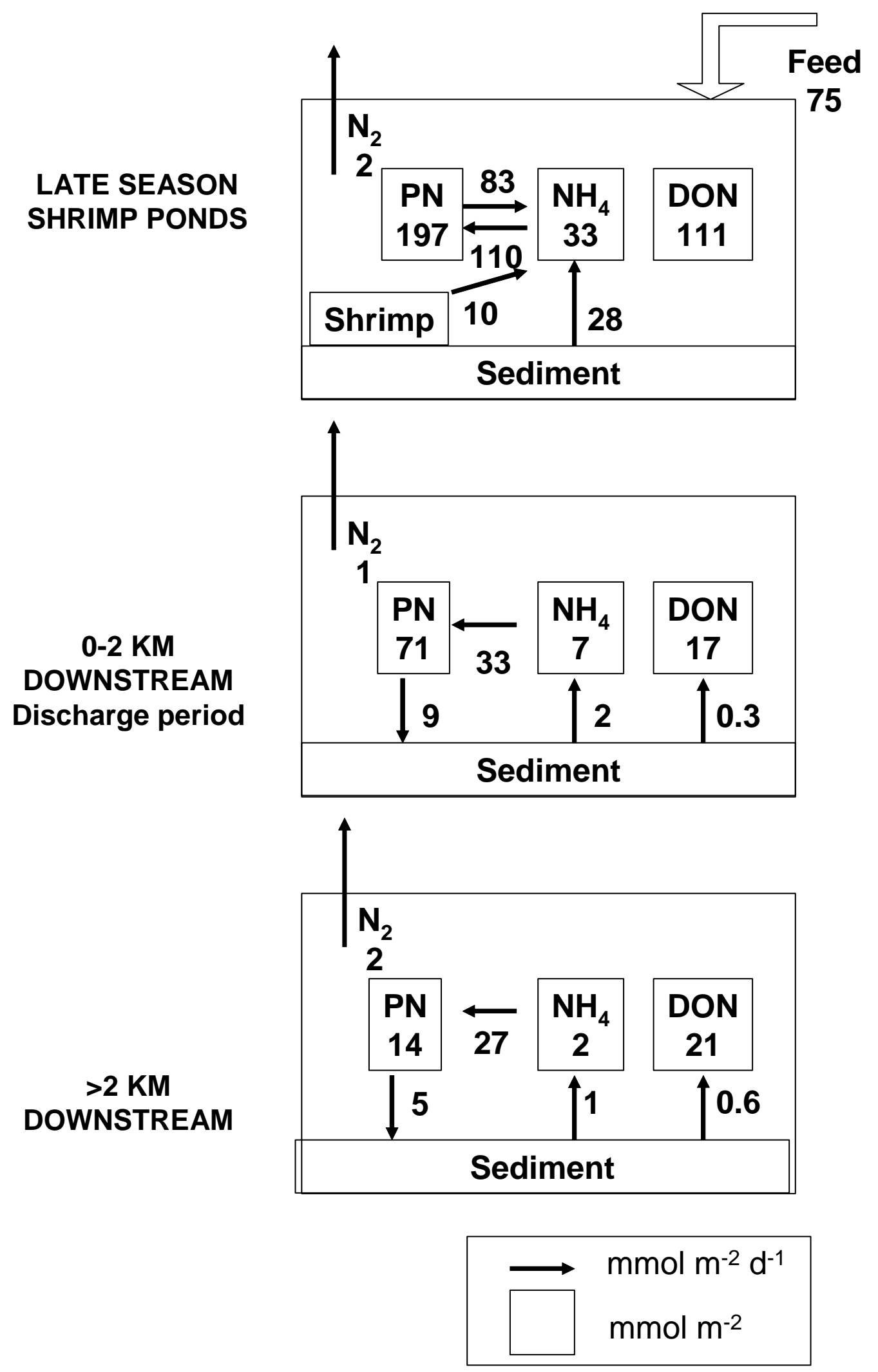



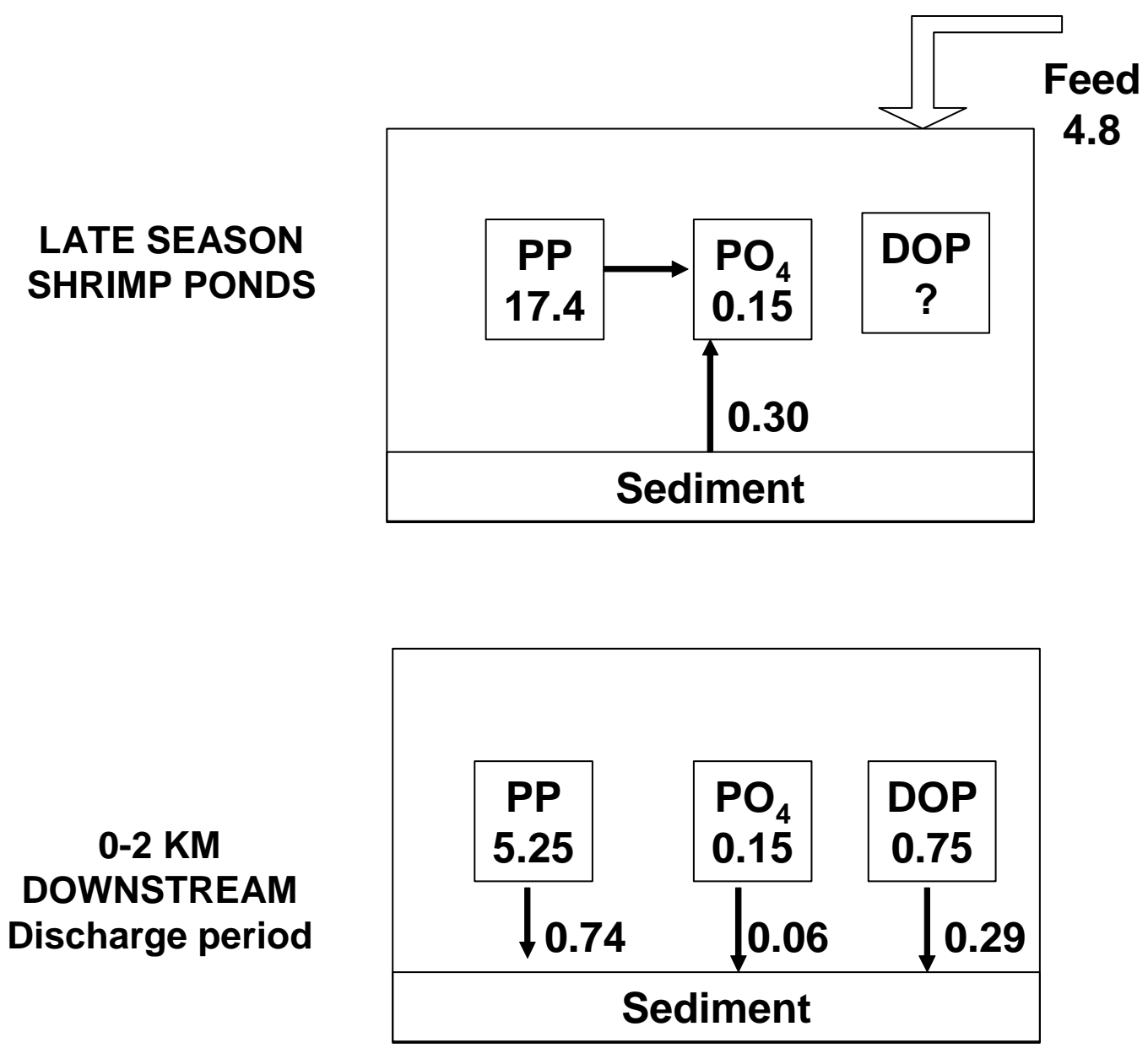

$>2 \mathrm{KM}$ DOWNSTREAM
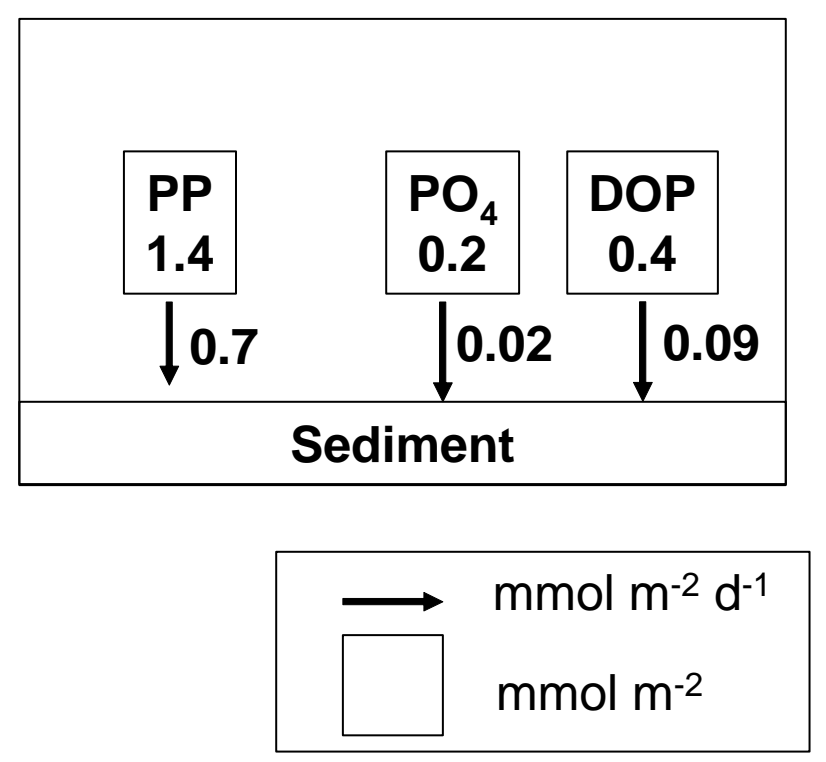